\title{
Impact of Krishi Vigyan Kendra on empowerment of tribal women: a study in Bastar district of Chhattisgarh
}

\author{
RATNA NASHINE*, NEELAM BHARADWAJ AND M. ESAKKIMUTHU \\ Department of Agricultural Extension and Communication, Govind Ballabh Pant University of \\ Agriculture and Technology, PANTNAGAR (UTTARAKHAND) INDIA
}

\begin{abstract}
Empowerment is a multidimensional social process that helps people to gain control over their own lives. Women empowerment generally refers to the process by which women enhances their power to take control over decisions that shape their livesin relation to access to resources participation in decision making and control over distribution benefits. Tribal women are the back bone of the tribal economy of Bastararea. Krishi Vigyan Kendra is one of the grassroot level agency which is engaged for upliftment of tribal women. Krishi Vigyan Kendra, Bastar had played significant role in improving the conditions of tribal women. The study was conducted in Bastar district. A total sample of 300 respondents was selected i.e. 150 beneficiaries and 150 nonbeneficiaries through population proportionate to sample size from six blocks representing 24 villages. A pre tested interview schedule was administered to 300 respondents. Relevant data on socio-personal, economic, psychological, and communication variables were collected. Difference between overall empowerment of beneficiaries and non-beneficiaries was worked out. It was concluded that majority of the respondents were middle aged, belonged to Muriya sub caste, illiterate, had joint family, married, involved in multiple occupation, small farmers with small land holdings, possessed kuchha house. The respondents belong to BPL category had 'medium' level of social participation, material possession, risk preference, self esteem, and extension contact, the respondent had 'high' level of mass media exposure and information seeking behaviour. Association with selected variables was calculated. There was significant difference between the extent of empowerment of beneficiaries and non-beneficiaries. In the documented programmes of Krishi Vigyan Kendra, it was found that in all the activities tribal women had participated. The activities of Krishi Vigyan Kendra had significant impact on the empowerment of the tribal women and they improved their skill, enhanced their income, upgraded technical knowledge and empowered them socially and economically.
\end{abstract}

KEY WorDS : Empowerment, Tribal women, Krishi Vigyan Kendra, Impact

View Point Article : Nashine, Ratna, Bharadwaj, Neelam and Esakkimuthu, M. (2015). Impact of Krishi Vigyan Kendra on empowerment of tribal women: a study in Bastar district of Chhattisgarh. Internat. J. Home Sci. Extn. \& Comm. Manage., 2 (1): 22-27.

Article History : Received : 17.09.2014; Revised : 23.11.2014; Accepted : 09.12.2014 